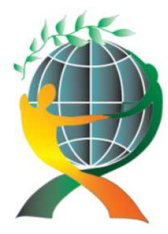

\author{
(online) $=$ ISSN $2285-3642$ \\ ISSN-L = $2285-3642$ \\ Journal of Economic Development, Environment and People \\ Volume 7, Issue 1, 2018
}

URL: $\underline{\text { http://jedep.spiruharet.ro }}$

e-mail: office jedep@spiruharet.ro

\title{
Efficiency and inefficiency of public administration
}

\author{
Roman Vavrek $^{1}$ \\ ${ }^{1}$ University of Prešov, Faculty of Management
}

\begin{abstract}
Public administration and local government in particular, which also includes municipalities in individual countries, is in the context of the economic crisis a very topical and widely discussed issue. The management of municipalities is subject to increasing control by the public, the state and the municipalities themselves. The aim of the presented paper is to offer a comprehensive definition of efficiency and methods that allow measuring it. As results of our analysis can be mentioned overview of TOPSIS technique application in a several studies.
\end{abstract}

Keywords: efficiency, effectiveness, evaluation methods, TOPSIS technique

JEL Codes: H72, H75, C39, C50

\section{Introduction}

If businesses want to survive and prosper in the public sector under the current global and competitive environment, they have to change their way of thinking and managing. [23] see efficiency as a key problem in the public sector. Efficiency means, according to [13], the most effective way of using its rare resources. $[11,18,20]$ see efficiency in a similar way. They consider it a state where the maximum amount of goods and maximum benefit can be obtained from available resources. According to [23], efficiency is a state where the economy is at the limit of its production possibilities.

One of the definitions is also offered by Act no. 502/2001 Coll. on the Financial Control, which describes efficiency as "maximizing the results of actions related to the available public funds". Moreover, this law describes efficiency as the most efficient use of public funds which aim is to achieve the highest possible quality of fulfilled tasks while spending the lowest possible amount of funds.

Efficiency can be seen from three angles:

- efficiency as an output - input, i.e. the relationship between revenues and expenditures, costs and benefits,

- efficiency as the ratio of actual output to standards (norms),

- efficiency as a success in fulfilling the intended goal.

[5] Points to the fact that there are two kinds of efficiency in the public sector:

- internal, which represents the rational behavior of the subject and 


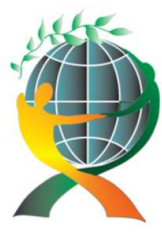

\author{
(online) $=$ ISSN $2285-3642$ \\ ISSN-L = $2285-3642$ \\ Journal of Economic Development, Environment and People \\ Volume 7, Issue 1, 2018 \\ URL: http://jedep.spiruharet.ro \\ e-mail: office jedep@spiruharet.ro
}

- external, defined by the quality of services and its external actions.

[9] points to the relationship between efficiency with equality/righteousness. Any change aimed at enhancing equality in society is associated with a certain loss of efficiency, primarily because of the following:

- state intervention is always associated with certain costs (administrative, transactional),

- redistribution of resources causes demotivating tendencies.

According to [23], there must always be a certain compromise between efficiency and righteousness. Excessive preference for efficiency leads to social instability in society; on the other hand, too much emphasis on righteousness slows down the economic growth and development. Another view of this issue offers $[1,4,8]$.

\title{
2. The relationship between efficiency and effectiveness
}

According to [20], effectiveness means the use of public funds in such a way that ensures the optimum level of achieved objectives. [11] see effectiveness as a degree to which the set objectives are met when the results of the expenditure activity are compared with the objectives in relation to the resources needed to achieve the objectives. According to Act no. 502/2001 Coll. (Section 2) effectiveness is the "relationship between the planned result of the activity and the actual result of the activity in terms of the public funds used". [14] sees the effectiveness as the higher performance measurement criterion. Despite the high efficiency of processes, however, their outputs may be pointless and therefore useless. A key role in determining and measuring effectiveness has the objectives that represent the expected future states (outcomes). After realization, the role of feedback is to ascertain how many goals have been met.

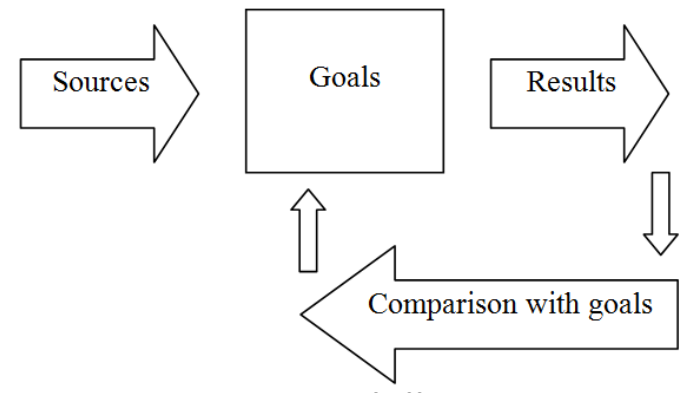

Fig. 1: The issue of effectiveness

Effectiveness indicators illustrate the relationship between services/products and the resources needed to produce them. Efficiency indicators show the quality of the action taken or the degree of fulfillment of the set objectives. One option is to measure timeliness and satisfaction rate of citizens (clients). Productivity indicators combine efficiency and effectiveness in one indicator. Another view of efficiency offers [6, 7] too. [19] illustrate the relationship between efficiency and effectiveness, as follows: 

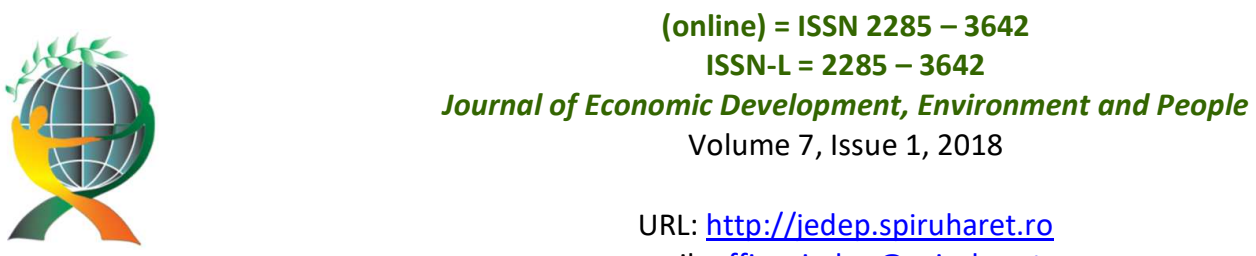

URL: http://jedep.spiruharet.ro

e-mail: office jedep@spiruharet.ro

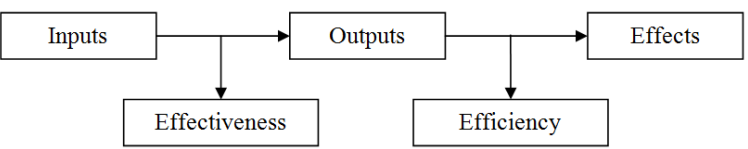

Fig. 2: Relationship between efficiency and effectiveness

\subsection{Inefficiency of public administration}

Public sector efficiency in the strict sense of the word, according to [18], is seen as a result of the relationship between inputs and outputs. According to [3], it is based on two conditions - Pareto efficiency and the individual efficiency associated with the creation of specific public goods. However, the tendency towards inefficiency is considered the main problem from the long-term point of view:

- the effort to maximize inputs of organizations,

- absence of intense pressure to reduce the costs,

- stagnation of outputs/minimizing organizational outputs.

According to [23], there is a tendency for inefficiency in the public sector due to the following reasons:

- no conditions for proper competition,

- there is no specific owner,

- no profit pressure,

- there is no risk of bankruptcy,

- public sector inputs can be easy to quantify, while outputs (benefits) are difficult to quantify,

- f) inputs are purchased at market prices and outputs are provided free of charge (at a tax price) or at a modified price (user fee),

- public sector activities are demanding in terms of professional competence.

[23] distinguishes between allocation and production inefficiency. Allocation inefficiency arises if the option chosen is incorrect or less effective than other variants. Productive inefficiency (technical) arises in the production of public goods when a worse path is chosen to achieve the stated goal.

Act no. 523/2004 Coll. on the Financial Rules of the Public Administration considers inefficient, uneconomic and ineffective spending of public funds to be financial discipline violation, while Act no. 502/2001 Coll. regulates the definition of the term efficiency, effectiveness and economic efficiency. Act 320/2001 Coll. on Financial Control regulates the effectiveness, efficiency and cost-effectiveness of the use of public funds by the public administration in the Czech Republic.

The efficiency of the public sector depends on its size and structure. According to [21], external factors affecting the size and structure of the public sector are as follows:

- political structure of society and the associated public elections and public scrutiny,

- the functioning of the market system - the taxpayer creates an atmosphere of efficiency through the amount of generated tax revenues thus regulating the financing of public services,

- the competitive environment within the public sector created by the public administration, 


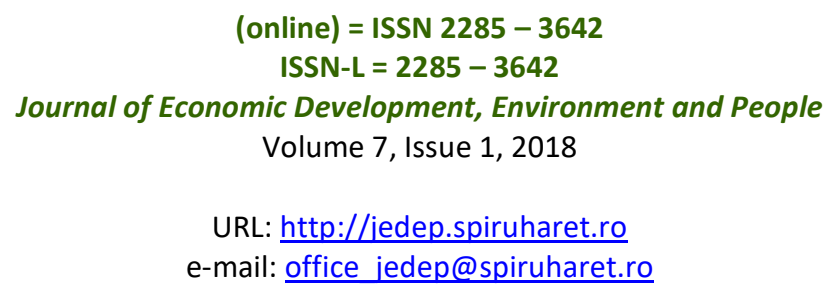

- financing of sectors and organizations of the public sector based on their performance and benefits they provide.

According to [16] the internal factors include:

- science and technology (use of knowledge from selected areas),

- structure of public activities in the organization (primary, secondary and management),

- all forms of labor division (horizontal and vertical),

- qualification of workers,

- workers' initiative (including ethics),

- the management system as the major factor of efficiency.

\subsection{Methods of efficiency evaluation}

Literature outlines several options to measure efficiency in the public administration. $[19,20,21,23$, 32] and others focus either on individual methods or group of methods. This chapter contains a list of individual efficiency measurement methods and a brief description of them. The breakdown follows the complexity of the methods used and identifies five categories of methods:

- evaluation methods based on one criterion,

- assessment methods based on a number of criteria,

- comparative methods,

- management evaluation methods,

- other selected evaluation methods.

In addition to the above-mentioned methods and practices, it is possible to increase the quality and efficiency of processes at the municipal level through competition, improved budget management and public scrutiny. [19]

\section{Evaluation methods based on one criterion}

The methods are based on one selected criterion (indicator). These methods are therefore easy to implement, however, they are the most distorted. These methods can be broken down:

- into financial indicators, e.g. net present value, internal rate of return, profitability index, payback time, profitability index, pay back, etc.,

- into "input-output" methods e.g. cost minimizing analysis (CMA), cost-benefit analysis (CBA), costeffectiveness analysis (CEA), cost-utility analysis (CUA).

These methods were created for the purposes of the private sector, i.e. businesses. However, their modifications can also be used to evaluate public sector efficiency.

Financial ratios (also referred to as investment rating methods) are dynamic and static, depending on whether calculations take into account time perspective. 


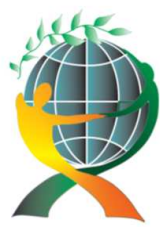

\author{
(online) $=$ ISSN $2285-3642$ \\ ISSN-L = $2285-3642$ \\ Journal of Economic Development, Environment and People \\ Volume 7, Issue 1, 2018
}

URL: $\underline{\text { http://jedep.spiruharet.ro }}$

e-mail: office jedep@spiruharet.ro

The common characteristic of input-output methods is the measurement of costs that were done in monetary units. The difference between them depends on how outputs are measured.

\begin{tabular}{|c|l|}
\hline Method & \multicolumn{1}{|c|}{ Output measurement } \\
\hline CMA & is not measured \\
\hline CBA & monetary units \\
\hline CEA & number of output units \\
\hline CUA & project's benefits \\
\hline
\end{tabular}

Table 1: Comparison of outputs of "input-output" methods

\title{
Evaluation methods based on multiple criteria
}

Efficiency evaluation based on multiple criteria is a more complicated option, but on the other hand, this evaluation gives more insight into the real state of public sector efficiency. According to [20] the basic advantage of these methods is the fact that they are not in a position to transform non-economic criteria into economic criteria at the cost of delicate, sometimes controversial operations. These methods include:

- scales and ranges (can be used separately or as a part of another method),

- methods of weight determination (equal importance, ranking, Fuller's method, Saaty's method),

- methods based on partial evaluation of variants (weighted sum method, basic variant),

- methods based on pair wise comparison of variants (lexicographic method, AHP, TOPSIS).

The method of equal importance is not able to distinguish between the greater or lesser importance of the observed criteria, i.e., each criterion is evaluated equally. Ranking is based on assigning a point value based on certain preferences. The scoring method is similar to the previous method, but works with cardinal variables (preference of individual indicators). The principle of the Fuller's method is to allocate the points to each pair of indicators and then to sum up the points obtained. $[25,26,27,28]$ used this method to evaluate municipalities in the Slovak Republic. Saaty's method works much like the previous methods. The only difference is that it also determines the size of this preference. The weighted sum method is particularly suited to determine quantitative criteria, assuming a linear dependence of the utility rate on criteria (indicators). The basic variant method determines the best or desired values and then calculates the utility rate of each alternative.

The lexicographic method is based on the assumption that the most important criterion has the greatest influence. In the case of compliance, the second and the next criterion shall be taken into account. When solving a problem the AHP method takes into consideration all the elements that affect the outcome (the links between them and the intensity with which they influence each other). The TOPSIS method chooses the variant that is closest to the pre-set ideal and at the same time the furthest from the basal variant. 


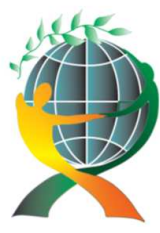

\author{
(online) $=$ ISSN $2285-3642$ \\ ISSN-L = $2285-3642$ \\ Journal of Economic Development, Environment and People \\ Volume 7, Issue 1, 2018 \\ URL: $\underline{\text { http://jedep.spiruharet.ro }}$ \\ e-mail: office jedep@spiruharet.ro
}

\title{
Technique for Order Preference by Similarity to Ideal Solution
}

According to [22], TOPSIS enables the decision maker to solve and analyze the problem, to compare alternatives and to rank them based on selected criteria. At the same time, this method is considered the most direct method of MCDM, while according to [17] this method is the most appropriate decision-making tool when it comes to incomplete data. According to [12, 22], the range of selected data is not determinant for its use, i.e. it is possible to use data of any range.

The perception of the advantages and disadvantages of this method differs due to their use in different situations and contexts. When comparing with other relevant methods (AHP, ELECTRE), [22] outline the following advantages of the TOPSIS method: the logic representing the rationality of human choice, the general value taking into account the best and worst values of the criteria, simple calculation which can be easily programmed or the result of alternatives can be illustrated by polyhedron (min. in 2 dimensions). [2] also add the following:

- easy use,

- the ability to work with all types of criteria (subjective and objective),

- rationality and understanding,

- the directness of the calculation,

- the concept illustrates the best alternative through mathematical calculations.

Since TOPSIS, as the MADM/MCDM method, is a practical tool for selecting and generating a number of alternatives, its application under different conditions varies. [15, 16] TOPSIS is used as the main decision maker in the "Asia Pacific Area". Its use was identified in manufactories, financial investment, sports teams' evaluation, automated processes. The method was also used to compare the performance of multiple companies and as a financial index for performance evaluation in a specific area that allowed detailed comparisons.

\section{Conclusion}

Efficiency or inefficiency of public administration is a current issue in many countries and at many levels. We could find a several alternatives how to measure it. TOPSIS method has been chosen for its above-mentioned attributes and advantages. We used this method to evaluate municipalities in the Slovak Republic with interesting findings:

- In Prešov district the municipal size and classified by TOPSIS technique is not a link. Modified weights had an impact on the ranking each year. In order for the whole period 2010 - 2012 these differences were minimal. [24]

- On the sample of municipalities from the Prešov Self-Governing Region (661 municipalities), the TOPSIS technique is applied in the first stage on the level of individual districts, followed by the application on the level of the whole region. The change of the sample file resulted in the change of the rankings of evaluated municipalities. Because of results identified above, we are inclined to the evaluation of municipalities in larger units (regions) that, according to us better describe their economy and offer a larger space for comparison or further evaluation. [30]

- By applying of the TOPSIS technique in Prešov self-governing region (661 municipalities), we 


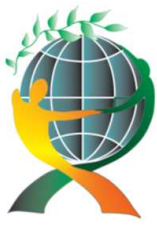

\author{
(online) $=$ ISSN $2285-3642$ \\ ISSN-L = $2285-3642$ \\ Journal of Economic Development, Environment and People \\ Volume 7, Issue 1, 2018 \\ URL: http://jedep.spiruharet.ro \\ e-mail: office jedep@spiruharet.ro
}

concluded that the weights themselves of selected criteria do not represent a factor that would significantly affect the overall evaluation of entities (municipalities). [31]

- The common sign for its application in districts of Bardejov, Prešov and Vranov nad Topl'ou is an imbalance of municipalities' economy or the high variation margin of results that is to a certain extent compensated through the evaluation in a time period longer than one year. Municipalities in these districts exhibit the same fixed linking to selected criteria (expect of Vranov nad Toplou district in three criteria). [28]

We consider the TOPSIS method to be a suitable multi-criterion assessment tool for the use of which it is necessary to have financial indicators (which in some cases may limit its use). Using it is also conditioned by the appropriate selection of the monitored indicators and their weighting, which significantly determines the overall results.

This article was elaborated as a part of grants VEGA $1 / 0578 / 18$, KEGA 038PU-4/2018 and VEGA $1 / 0139 / 16$

\title{
4. References
}

[1] ADAMIŠIN, P. and E. HUTTMANOVÁ, 2013. The analysis of the energy intensity of economies by selected indicators of sustainability (Rio+ 20). In: Journal of Economic Development, Environment and People. Issue 2, no. 1, pp. 7-18. ISSN 2285-3642.

[2] BHUTIA, P. W. and R. PHIPON, 2012. Application of AHP and TOPSIS Method for Supplier Selection Problem. In: Journal of Engineering. Issue 2, no. 10. pp. 43-50. ISSN 2278-8719.

[3] CIBÁKOVÁ, V. and V. NINÁČOVÁ, 2006. Základy ekonomiky verejného sektora. Bratislava: Merkury. ISBN 8089143-25-3.

[4] DUBRAVSKÁ, M., 2014. Recycling of the MSW in the Slovak Republic. In: Journal of Economic Development, Environment and People. Issue 3, no. 3, pp. 66-71. ISSN 2285-3642.

[5] FANTOVÁ ŠUMPÍKOVÁ, M., 2006. Hodnocení efektivnosti veřejných výdajových programů: habilitačná práca. Brno: Masaryk university.

[6] FRIDGEIRSSON, T., V., 2015. Benchmarking, planning and decision making procedures in public projects. In: Journal of Global Strategic Management. Issue 9, no. 2, pp. 5-14. ISSN 1307-6205.

[7] CHAUDHARY, G. M. and Z. ABBAS, 2017. Global Financial Crisis And Its Impact On Efficiency And Performance Of Commercial Banks In Pakistan. In: Journal of Business Studies Quarterly. Issue 8, no. 4, pp. 15-29. ISSN 2152-1034.

[8] CHOVANCOVÁ, J. and H. HARAUSOVÁ, 2013. Education of the next generation of managers in context of green economy. In: Journal of Economic Development, Environment and People. Issue 2, no. 1, pp. 57-68. ISSN 22853642.

[9] HALÁSEK, D. et al., 2004. Rozhodování ve veřejném sektoru. 1. edit. Ostrava: VŠB - Technická univerzita Ostrava. ISBN 80-248-0570-7.

[10] HALÁSEK, D., J. PILNÝ and P. TOMÁNEK, 2002. Určování bonity obcí. Ostrava: VŠB - Technická univerzita Ostrava. ISBN 80-248-0159-0. 


\author{
(online) $=$ ISSN $2285-3642$ \\ ISSN-L = 2285 - 3642 \\ Journal of Economic Development, Environment and People \\ Volume 7, Issue 1, 2018 \\ URL: http://jedep.spiruharet.ro \\ e-mail: office jedep@spiruharet.ro
}

[11] HAMERNÍKOVÁ, B. and A. MAAYTOVÁ et al., 2010. Veřejné finance. 2. edit. Prague: Wolters Kluwer ČR. ISBN 97880-7357-497-0.

[12] KANDAKOGLU, A., M. CELIK and I. AKGUN, 2009. A multi-methodological approach for shipping registry selection in maritime transportation industry. In: Mathematical and Computer Modelling. Issue 2009, no. 49, pp. 586-597. ISSN 0895-7177.

[13] MANKIW, N., 2000. Zásady ekonomie. 2. edit. Prague: Grada. ISBN 80-71698-91-1.

[14] OCHRANA, F., 2003. Veřejná volba a ř́zení veřejných výdavků.1. edit. Prague: Ekopress. ISBN 80-86119-71-8.

[15] OSTASI, B., ONAR, B. S. and C. KAHRAMAN, 2017. Selection among innovative project proposals using a hesitant fuzzy multiple criteria decision making method. In: Journal of Economics, Finance and Accounting, Issue 2, no. 4, pp. 192-200. ISSN 2148-6697.

[16] OZEN, E., YESILDAG, E. and M. SOBA, 2015. TOPSIS performance evaluation measures and relation between financial ratios and stock returns. In: Journal of Economics, Finance and Accounting, Issue 4, no. 2, pp. $482-500$. ISSN 2148-6697.

[17] PAVIC, Z. and V. NOVOSELAC, 2013. Notes on TOPSIS Method. In: International Journal of Research in Engineering and Science. Issue 1, no. 2. pp. 5-12. ISSN 2320-9356.

[18] PEKOVÁ, J., 2011. Finance územní samosprávy: teorie a prax v ČR. 1. edit. Prague: Wolters Kluwer ČR. ISBN $978-$ 80-7357-614-1.

[19] PROVAZNÍKOVÁ, R., 2009. Financování měst, obcí a regionů: teorie a praxe. 2 edit. Prague: GRADA Publishing. ISBN 978-80-247-2789-9.

[20] REKTOŘÍK, J., J. ŠELEŠOVSKÝ et al., 2003. Kontrolní systémy veřejné správy a veřejného sektoru. 1. edit. Prague: Ekopress. ISBN 80-86119-72-6.

[21] ŠEBESTOVÁ, J., 2008. Kontrolní systém veřejné správy a veřejného sektoru. Karviná: Silesion university in Opava. ISBN 978-80-7248-460-7.

[22] SHIH, H., H. SHYUR and E.S. LEE, 2007. An extension of TOPSIS for group decision making. In: Mathematical and Computer Modelling. Issue 2007, no. 45, pp. 801-813. ISSN 0895-7177.

[23] TETŘEVOVÁ, L., 2008. Veřejná ekonomie. 1. edit. Př́bram: PBtisk Příbram. ISBN 978-80-86946-79-5.

[24] VAVREK, R. and P. ADAMIŠIN, 2013. Impact of weight indicators of TOPSIS technique in the selected district in the Slovak Republic. In: Journal of Economic Development, Environment and People. Issue 2, no. 4, pp. 61-73. ISSN 2285-3642.

[25] VAVREK, R., 2017. Multi-criteria evaluation of municipalities. Warsawa: Jedność w róznorodości, 142 s. - ISBN 978-83-947394-6-1.

[26] VAVREK, R., 2017. Váha parametru TOPSIS techniky a jeho vplyv na hodnotenie obcí v Slovenskej republike. In: Scientific Papers of the University of Pardubice. Issue 14, no. 39, pp. 236-246. ISSN 1211-555X.

[27] VAVREK, R., KRAVČÁKOVÁ VOZÁROVÁ, I., CEHLÁROVÁ, M. and I. ONDRIJOVÁ, 2014. The municipality as a source of information? In: Journal of Economic Development, Environment and People. Issue 3, no. 3, pp. 41-48. ISSN 2285-3642.

[28] VAVREK, R., P. ADAMIŠIN and R. KOTULIČ, 2017. Multi-criteria evaluation of municipalities in Slovakia - case study in selected districts. In: Polish Journal of Management Studies. Issue 16, no. 2, pp. 290-301. ISSN 20817452.

[29] VAVREK, R., R. KOTULIČ and P. ADAMIŠIN, 2014. TOPSIS Method and Its Application to the Local Self-Government of the Slovak Republic. In: Journal of Applied Economic Sciences. Issue 3, no. 3, pp. 504-512. ISSN 1843-6110. 


\author{
(online) $=$ ISSN $2285-3642$ \\ ISSN-L = 2285 - 3642 \\ Journal of Economic Development, Environment and People \\ Volume 7, Issue 1, 2018 \\ URL: http://jedep.spiruharet.ro \\ e-mail: office jedep@spiruharet.ro
}

[30] VAVREK, R., R. KOTULIČ and P. ADAMIŠIN, 2015. District as a Determinant of the Evaluation of Municipalities Economy?. In: Journal of Applied Mathematics and Statistics. Issue 53, no. 3, pp. 12. ISSN 0973-1377.

[31] VAVREK, R., R. KOTULIČ and P. ADAMIŠIN, 2015. Evaluation of Municipalities Management with the TOPSIS Technique Emphasising on the Impact of Weights of Established Criteria. In: Lex localis - Journal of Local SelfGovernment. Issue 13, no. 2, pp. 249-264. ISSN 1581-5374.

[32] VRABKOVÁ, I., 2012. Perspektivy ř́zení kvality ve veřejné správě. Ostrava: VŠB - Technická univerzita Ostrava. ISBN 978-80-248-2939-5. 